\title{
Pembelajaran Kooperatif Tipe Berpikir Berpasangan Berbagi untuk Meningkatkan Aktivitas dan Hasil Belajar Matematika Siswa Kelas X Multimedia SMKN 1 Praya Tengah
}

\author{
Ahmad Sardan \\ SMKN 1 Praya Tengah, Kabupaten Lombok Tengah - Provinsi NTB \\ *Corresponding Author. Email: ahmadsardan@gmail.com
}

\begin{abstract}
This study aims to improve the activities and learning outcomes of students of SMKN 1 Praya Tengah Class X Multimedia through cooperative learning, thinking in pairs and sharing. This research method uses classroom action research with 20 students as research subjects. The instruments of this research are observation sheets and tests. While the data analysis technique used quantitative descriptive analysis. The results showed an increase in student activity and learning outcomes, namely in the first cycle the average score of student learning activities was 10.3 with a fairly active category, while the average value of student learning outcomes was 66 and the percentage of completeness was $80 \%$. In cycle II the average score of student learning activities is 14.22 with a very active category, while the average value of student learning outcomes is 75 and the percentage of completeness is $90 \%$. So that the results of this study conclude that cooperative learning in thinking in pairs and sharing can increase the activity and learning outcomes of mathematics students at SMKN 1 Praya Tengah Class X Multimedia.
\end{abstract}

\begin{abstract}
Abstrak: Penelitian ini bertujuan untuk meningkatkan aktivitas dan hasil belajar matematika siswa SMKN 1 Praya Tengah Kelas X Multimedia melalui pembelajaran kooperatif berfikir berpasangan berbagi. Metode penelitian ini menggunakan penelitian tindakan kelas dengan subyek penelitiannya sebanyak 20 siswa. Instrument penelitian ini adalah lembar observasi dan tes. Sedangkan teknik analisis datanya menggunakan analisis deskriptif kuantitatif. Hasil penelitian menunjukkan adanya peningkatan aktivitas dan hasil belajar siswa yaitu pada siklus I skor rata-rata aktivitas belajar siswa sebesar 10,3 dengan katagori cukup aktif, sedangkan nilai rata-rata hasil belajar siswa sebesar 66 dan persentase ketuntasannya $80 \%$. Pada siklus II skor rata-rata aktivitas belajar siswa sebesar 14,22 dengan katagori sangat aktif, sedangkan nilai rata-rata hasil belajar siswa 75 dan persentase ketuntasannya 90\%. Sehingga hasil penelitian ini menyimpulkan bahwa pembelajaran kooperatif berfikir berpasangan berbagi dapat meningkatkan aktivitas dan hasil belajar matematika siswa SMKN 1 Praya Tengah Kelas X Multimedia.
\end{abstract}

Article History

Received: 07-11-2021

Revised: 28-11-2021

Accepted: 10-12-2021

Published: 07-01-2022

Key Words:

Cooperative, Thinking in

Pairs Sharing, Learning

Activities, Learning

Outcomes.

\section{Sejarah Artikel}

Diterima: 07-11-2021

Direvisi: $28-11-2021$

Disetujui: 10-12-2021

Diterbitkan: 07-01-2022

\section{Kata Kunci:}

Kooperatif, Berpikir

Berpasangan Berbagi,

Aktivitas Belajar, Hasil

Belajar

How to Cite: Sardan, A. (2022). Pembelajaran Kooperatif Tipe Berpikir Berpasangan Berbagi untuk Meningkatkan Aktivitas dan Hasil Belajar Matematika Siswa Kelas X Multimedia SMKN 1 Praya Tengah. Jurnal Paedagogy, 9(1), 69-77. doi:https://doi.org/10.33394/jp.v9i1.4446

do)

https://doi.org/10.33394/jp.v9i1.4446

This is an open-access article under the CC-BY-SA License.

\section{Pendahuluan}

Pembelajaran pada hakikatnya merupakan suatu proses interaksi baik secara langsung maupun tidak langsung. Secara langsung dengan melalui tatap muka dan secara tidak langsung yaitu dengan menggunakan berbagai media yang inovarif (Saufi \& Rizka, 2021; Sya'i et al., 2021). Guru merupakan penyebab utama bagi terjadinya proses belajar siswa meskipun tidak setiap perbuatan belajar siswa merupakan akibat guru mengajar. Walaupun demikian Guru mempunyai peran yang utama dalam melaksanakan dan menyajikan sebuah program pembelajaran yang efektif dan efisien. Proses pembelajaran yang efektif dan efisien 
dapat terlaksana jika persiapan guru matang dan terprogram dengan maksimal (Djamarah, 2002). Dengan pembelajaran yang efektif dan efisien diharapkan dapat meningkatkan hasil belajar siswa menjadi lebih baik (Hamalik, 2010).

Perkembangan zaman menuntut kualitas sumber daya manusia ke arah yang lebih maju sesuai dan seiring dengan kemajuan teknologi. Untuk menguasai teknologi salah satu mata pelajaran yang harus banyak dikuasai siswa adalah mata pelajaran Matematika. Tugas seorang guru bukan hanya sekedar mengajar melainkan bagaimana menciptakan suasana yang kondusif yang dilakukan dengan berbagai cara. Pembelajaran tidak akan sukses dengan hanya menggunakan satu cara atau pola tertentu yang dilakukan secara terus menerus. Jika seorang guru mengajar dengan satu pola tertentu pada tiap sub pokok bahasan, maka tidak akan mendapatkan hasil yang memuaskan, tetapi apabila seorang guru mengemas pola pembelajarannya dengan berbagai cara supaya pembelajarannya menarik, maka hasilnya akan memuaskan serta tahan lama (Isjono, 2010; Lie; 2010).

Berdasarkan hasil observasi awal penelitian ini bahwa aktivitas dan hasil belajar matematika siswa kelas X Multimedia di di SMKN 1 Praya Tengah masih tergolong rendah. Hal ini disebabkan salah satunya adalah faktor pemilihan model pembelajaran yang kurang tepat, karena selama ini guru lebih memilih menggunakan pembeljaran secara konvensional. Dengan permasalahan tersebut, penelitian ini berupaya untuk meningkatkan aktivitas dan hasil belajar Matematika siswa dengan menggunakan pembelajaran kooperatif tipe berpikir berpasangan berbagi yang menekankan pada siswa untuk dapat berperan aktif dalam proses pembelajaran, sehingga dapat meningkatkan hasil belajar peserta didk pada mata pelajaran matematika. Selain itu, melalui pembelajaran kooperatif, siswa dapat bekerjasama, saling membantu dan bertanggung jawab dalam aktivitas belajar (Wirejati, 2019; Burungge, 2020; Taqiya et. Al., 2021; Israil, 2019; Yuliati, 2018). Adapun penelitian ini bertujuan untuk meningkatkan aktivitas dan hasil belajar matematika siswa SMKN 1 Praya Tengah Kelas X Multimedia melalui pembelajaran kooperatif berfikir berpasangan berbagi.

\section{Metode Penelitian}

Metode penelitian ini adalah penelitian tindakan kelas yang dilakukan oleh guru di dalam kelasnya sendiri melalui refleksi diri dengan tujuan untuk memperbaiki kinerjanya sebagai guru, sehingga hasil belajar siswa menjadi meningkat (Corebima, 2009). Subyek penelitian ini adalah siswa kelas X Multimedia SMKN 1 Praya Tengah yang terdiri dari 20 siswa dengan komposisi 10 siswa laki-laki dan 10 siswi perempuan. Prosedur yang digunakan dalam penelitian ini adalah prosedur penelitian tindakan kelas. Penelitian tindakan kelas secara garis besar terdapat empat tahapan yang lazim dilalui, yaitu: (1) perencanaan, (2) pelaksanaan tindakan, (3) pengamatan, dan (4) refleksi, yang merupakan langkah berurutan dalam satu siklus yang berhubungan dengan siklus berikutnya. Instrument penelitian ini menggunakan lembar observasi aktivitas siswa, observasi aktivitas guru, dan tes. Setiap indikator terdiri dari 3 deskriptor, dimana skor aktivitas siswa secara klasikal untuk masingmasing deskriptor, yaitu:

Tabel 1. Pedoman Pemberian Skor Aktivitas Siswa

\begin{tabular}{cc}
\hline Skor & Kriteria pemberian skor \\
\hline 0 & $\mathrm{X} \leq 25 \%$ \\
\hline 1 & $25 \%<\mathrm{X} \leq 50 \%$ \\
\hline 2 & $50 \%<\mathrm{X} \leq 75 \%$ \\
\hline 3 & $\mathrm{X}>75 \%$ \\
\hline
\end{tabular}


$\mathrm{X}=$ banyaknya siswa yang aktif melakukan aktivitas sesuai deskriptor.

1. Data tentang aktivitas guru di dalam kelas diambil dengan menggunakan lembar observasi pada tiap siklus. Penilaian terhadap aktivitas guru dilakukan melalui observasi langsung dimana seorang guru yang sedang mengajar diobservasi langsung oleh observer dan observer bersama-sama guru dan siswa di dalam kelas. Sedangkan data mengenai aktivitas guru diambil dengan menggunakan lembar observasi berupa lembar aktivitas. Indikator untuk aktivitas guru adalah sebagai berikut:

a) Perencanaan dan persiapan penyelenggaraan pembelajaran.

b) Pemberian motivasi dan apersepsi kepada siswa.

c) Pengaturan kegiatan diskusi.

d) Membimbing siswa dalam kegiatan diskusi.

e) Memamerkan hasil karya siswa.

f) Membimbing siswa dalam mengerjakan latihan soal.

g) Menutup pembelajaran.

Setiap indikator terdiri dari 3 deskriptor. Dimana indikator aktivitas guru ditentukan berdasarkan kriteria penilaian sebagai berikut:

Tabel 2. Pedoman Konversi Aktivitas Guru

\begin{tabular}{ll}
\hline \multicolumn{1}{c}{ Deskriptor yang Nampak } & \multicolumn{1}{c}{ Tingkatan } \\
\hline Jika semua deskriptor (3) yang Nampak & BS (Baik Sekali) \\
\hline Jika ada 2 deskriptor yang Nampak & B (Baik) \\
\hline Jika ada 1 deskriptor yang Nampak & C (Cukup) \\
\hline Jika tidak ada deskriptor yang Nampak & K(Kurang) \\
\hline
\end{tabular}

Data tentang hasil belajar siswa dianalisis secara deskriptif kuantitatif dan kualitatif. Sedangkan kualifikasi prestasi belajar siswa diperoleh dengan pedoman konversi seperti tabel 3 berikut:

Tabel 3. Pedoman Konversi Skor Hasil Belajar Siswa

\begin{tabular}{ccc}
\hline No & Skor & Kategori \\
\hline 1 & $85-100$ & Sangat Baik \\
\hline 2 & $70-84$ & Baik \\
\hline 3 & $55-69$ & Cukup \\
\hline 4 & $40-54$ & Kurang \\
\hline 5 & $0-39$ & Sangat Kurang \\
\hline
\end{tabular}

Untuk mengetahui adanya peningkatan hasil belajar siswa pada pembelajaran matematika yang dicapai pada tiap siklus, digunakan rumus sebagai berikut:

Menentukan rata-rata

$$
\overline{\boldsymbol{X}}=\frac{\text { Jumlah Nilai Siswa }}{\text { Jumlah Siswa Yang Mengikuti Tes }}
$$

Setiap siswa dalam proses belajar mengajar dikatakan tuntas secara individu terhadap materi pelajaran yang disajikan apabila siswa mampu memperoleh nilai $\geq \mathrm{KKM}$.

$K K=\frac{X}{N} x 100 \%$

Dengan KK menyatakan ketuntasan klasikal, $\mathrm{X}$ menyatakan jumlah siswa yang memperoleh nilai $\geq \mathrm{KKM}$, dan $\mathrm{N}$ menyatakan jumlah siswa sesuai dengan petunjuk teknik penilaian. Kelas dikatakan tuntas secara klasikal terhadap materi pelajaran yang disajikan jika ketuntasan klasikal mencapai $85 \%$. 


\section{Hasil Penelitian dan Pembahasan Deskripsi Siklus I \\ Perencanaan}

Pada tahap perencanaan peneliti menyusun perangkat pembelajaran yang meliputi penyusunan rencana pelaksanaan pembelajaran (RPP), membentuk kelompok yang memiliki kemampuan akademik heterogen dengan anggota 4-5 orang, pedoman observasi aktivitas siswa, menyiapkan lembar kerja siswa (LKS) sebagai bahan diskusi, dan membuat soal evaluasi siklus I lengkap dengan kunci jawaban.

\section{Pelaksanaan tindakan}

Kegiatan yang dilakukan pada tahap ini adalah melaksanakan pembelajaran sesuai dengan Rencana Pelaksanaan Pembelajaran (RPP) siklus I. Pada awal pembelajaran guru memperkenalkan diri, mensosialisasikan metode yang akan digunakan dalam pembelajaran, menyampaikan tujuan pembelajaran, dan mengabsen kehadiran siswa. Adapun langkah yang ditempuh adalah: (1) Guru melaksanakan pembelajaran dengan menjelaskan materi pelajaran. (2) Guru mengamati pemahaman konsep yang telah dikuasai siswa, melalui metode tanya jawab. Siswa diberikan kesempatan bertanya terhadap materi yang belum jelas. (3) Guru bersama-sama siswa membentuk kelompok yang beranggotakan 4 orang. Ketua kelompok dipilih sesuai kesepakatan dari masing-masing kelompok. (4) Guru membagikan siswa LKS kemudian siswa diminta mengerjakan LKS secara individu dengan batas waktu yang sudah ditentukan. (5) Setelah mengerjakannya secara individu siswa kemudian berpasangan dengan teman sebangkunya. Setelah berdiskusi dengan teman sebangku, siswa bergabung dengan kelompok dan membahas hasil kerjanya dipimpin oleh ketua kelompok. (6) Masing-masing wakil dari anggota kelompok secara bergiliran mempresentasikan di depan kelas, siswa yang lain memperhatikan dan memberi tanggapan. Setelah diskusi berakhir, guru memberikan soal latihan yang dijawab bersama dan beberapa pertanyaan untuk mengingatkan materi yang sudah dibahas. Setelah itu guru bersama-sama dengan siswa menyimpulkan apa yang telah dipelajari.

\section{Observasi Aktivitas Guru}

Hasil observasi aktivitas guru dapat dilihat pada tabel 4 berikut ini.

\begin{tabular}{ccc}
\multicolumn{3}{c}{ Tabel 4. Hasil Perhitungan Aktivitas Guru Siklus I } \\
\hline Pertemuan & Skor aktivitas guru & Katagori \\
\hline 1 & 1,71 & Cukup \\
\hline 2 & 2 & Baik \\
\hline 3 & 2,71 & Baik \\
\hline
\end{tabular}

Dari hasil observasi terhadap kemampuan guru mengelola kelas dan kelompok diperoleh temuan sebagai berikut.

1) Guru tidak memastikan kelengkapan alat belajar siswa, sehingga ketika diskusi tengah berlangsung, ada beberapa orang siswa yang meminta izin untuk mengambil kelengkapan belajar yang mereka lupakan.

2) Dalam menyampaikan materi, guru belum melibatkan siswa secara aktif.

3) Dalam menyampaikan materi, guru terlalu cepat sehingga beberapa siswa kurang memahami materi yang disampaikan oleh guru.

4) Guru belum dapat mengatur waktu untuk masing-masing item kegiatan yang harus dilakukan siswa sebagaimana yang telah disusun dalam Rencana Pelaksaaan Pembelajaran (RPP). Waktu yang dihabiskan lebih banyak dari yang telah direncanakan dalam RPP. 


\section{Observasi Aktivitas Siswa}

Data mengenai hasil observasi aktivitas siswa untuk siklus I didapatkan bahwa nilai rata-rata aktivitas siswa adalah 9,5 dengan kriteria cukup aktif. Ringkasan hasil observasi aktivitas siswa dapat dilihat pada tabel 5.

Tabel 5. Ringkasan Hasil Aktivitas Siswa Siklus I

\begin{tabular}{ccc}
\hline Pertemuan & Skor aktivitas siswa & Katagori \\
\hline 1 & 8,33 & Cukup aktif \\
\hline 2 & 10,67 & Aktif \\
\hline 3 & 12,01 & Aktif \\
\hline
\end{tabular}

Berdasarkan hasil observasi aktivitas siswa di atas, selama proses pembelajaran dengan tipe berpikir berpasangan berbagi secara umum dapat dikatakan sudah terlaksana dengan baik. Namun ada beberapa hal yang perlu diperbaiki pada siklus berikutnya yaitu:

1) Ada siswa yang belum memahami penjelasan guru mengenai materi yang disampaikan oleh guru.

2) Sebagian siswa belum bisa memanfaatkan kesempatan untuk berdiskusi dengan teman kelompoknya.

3) Siswa masih terlihat takut untuk bertanya.

4) Pembagian tugas untuk masing-masing siswa dalam kelompok masih belum jelas sehingga tugas-tugas dalam kelompok dikerjakan oleh satu-dua orang saja

5) Sebagian siswa belum bisa menyimpulkan materi yang mereka diskusikan.

6) Hanya beberapa siswa yang mengecek jawabannya atau mencatat jawaban yang benar dari soal latihan yang diberikan.

\section{Hasil Evaluasi}

Evaluasi belajar siswa diadakan pada akhir pertemuan dengan cara memberikan tes berbentuk pilihan ganda sebanyak 10 soal yang dikerjakan dalam waktu dua jam pelajaran. Ringkasan hasil evaluasi siswa dapat dilihat pada tabel 6.

\section{Tabel 6. Ringkasan Hasil Evaluasi Siklus I}

\begin{tabular}{lc}
\hline Jumlah siswa yang mengikuti tes & 20 \\
\hline Jumlah siswa yang tuntas & 16 \\
\hline Jumlah siswa yang tidak tuntas & 4 \\
\hline Nilai tertinggi & 80 \\
\hline Nilai terendah & 40 \\
\hline Rata-rata nilai hasil belajar & 66 \\
\hline Prosentase ketuntasan & $80 \%$
\end{tabular}

Dari tabel diatas dapat dilihat bahwa dari 20 siswa yang mengikuti evaluasi, terdapat 16 siswa yang tuntas dan 4 siswa tidak tuntas, sehingga ketuntasan belajar siswa pada siklus I ini mencapai $80 \%$ dengan nilai rata-rata 66 .

\section{Refleksi}

Dilihat dari hasil yang diperoleh dari siklus I, ternyata belum mencapai hasil yang diharapkan. Ketuntasan klasikal hanya mencapai $80 \%$ sedangkan ketuntasan yang ditetapkan adalah $85 \%$. Hasil observasi juga menunjukkan hasil yang kurang memuaskan. Untuk itu peneliti mengadakan penyempurnaan dan perbaikan terhadap kekurangan-kekurangan yang muncul pada siklus I. Adapun tindakan-tindakan perbaikan yang akan ditempuh adalah:

1) Dalam menyampaikan materi guru lebih melibatkan siswa secara aktif. 
2) Guru meminta tiap kelompok untuk mendiskusikan terlebih dahulu tugas dari masingmasing siswa dalam kelompok agar kegiatan pembelajaran terarah dan semua siswa aktif dalam diskusi.

3) Sebelum pembelajaran selesai guru meminta siswa untuk mencatat jawaban benar yang telah didiskusikan bersama.

4) Guru lebih mengatur alokasi waktu dalam setiap kegiatan selama pembelajaran berlangsung.

\section{Deskripsi Siklus II}

Pelaksanaan siklus II ini pada dasarnya sama urutannya dengan pelaksanaan pada siklus I. Namun pada siklus II ini merupakan tahap penyempurnaan dari tahap siklus I. Tahap pelaksanaan penelitian siklus II sama dengan siklus I yang dimulai dari perencanaan, pelaksanaan tindakan, observasi, dan refleksi.

\section{Perencanaan}

Perencanaan siklus II tidak jauh beda dengan pelaksanaan siklus I. Pada tahap perencanaan ini juga dilakukan persiapan-persiapan sebagai berikut.

1) Meyiapkan kembali perangkat pembelajaran yang meliputi penyusunan rencana pelaksanaan pembelajaran, kelompok yang memiliki kemampuan akademik heterogen dengan anggota 4-5 orang, pedoman observasi aktivitas siswa, menyiapkan lebar kerja siswa (LKS) sebabagai bahan diskusi, dan membuat soal evaluasi siklus II lengkap dengan kunci jawaban.

2) Memeriksa kembali prasarana yang diperlukan siswa dalam menyelesaikan LKS dan soal evaluasi. Prasarana yang dimaksud antara lain penggaris, kertas buram, pensil dan lain sebagainya.

\section{Pelaksanaan Tindakan}

Pelaksanaan tindakan pada siklus ini hampir sama dengan pelaksanaan tindakan pada siklus sebelumnya. Guru melaksanakan pembelajaran sesuai dengan rencana pelaksanaan pembelajaran (RPP) yaitu dengan menjelaskan materi kemudian guru membagikan LKS kepada setiap siswa. Setelah itu guru mengorganisasikan siswa dalam kelompok-kelompok yang terbentuk pada siklus I dan siswa belajar dengan langkah-langkah yang ada pada model pembelajaran kooperatif tipe berpikir berpasangan berbagi. Selama diskusi berlangsung guru memantau kerja tiap-tiap kelompok dan membimbing siswa yang mengalami kesulitan. Setelah diskusi selesai guru bersama-sama siswa menyimpulkan materi yang telah didiskusikan dan memperbaiki hasil presentasi siswa yang belum sesuai dengan konsep yang benar.

\section{Hasil Observasi Aktivitas Guru}

Data yang diperoleh dari observasi aktivitas guru dapat dilihat pada tabel 7 berikut ini.

\section{Tabel 7. Hasil Perhitungan Aktivitas Guru Siklus II}

\begin{tabular}{ccc}
\hline Pertemuan & Skor Aktivitas Guru & Kategori \\
\hline 1 & 2,71 & Baik \\
\hline 2 & 2,86 & Sangat baik \\
\hline 3 & 3 & Sangat baik \\
\hline
\end{tabular}

Secara umum, guru sudah berusaha untuk melaksanakan kegiatan pembelajaran sesuai dengan Rencan Pelaksanaan Pembelajaran (RPP). Pengaturan waktu dilakukan dengan baik, melakukan pemantuan dan bimbingan secara merata pada tiap kelompok, menyampaikan 
kesimpulan materi dan memperbaiki hasil presentasi kelompok yang tidak sesuai dengan konsep yang benar.

\section{Hasil Observasi Aktivitas Sisiwa}

Data mengenai hasil observasi aktivitas siswa untuk siklus II dapat dilihat pada lampiran. Dari data tersebut, bahwa nilai rata-rata aktivitas siswa sebesar 13,5 dengan kriteria sangat aktif. Ringkasan hasil observasi siswa dapat dilihat pada tabel 8.

Tabel 8. Ringkasan Hasil Aktivitas Siswa Siklus II

\begin{tabular}{ccc}
\hline Pertemuan & Skor Aktivitas Siswa & Katagori \\
\hline 1 & 13,34 & Aktif \\
\hline 2 & 14,33 & Sangat aktif \\
\hline 3 & 14,99 & Sangat aktif \\
\hline
\end{tabular}

Pada tabel di atas menunjukkan bahwa kriteria keaktifan siswa sudah tercapai. Ada peningkatan skor rata-rata aktivitas siswa dari siklus I. Dari hasil observasi aktivitas siswa pada siklus II didapatkan bahwa siswa antusias dengan model pembelajaran yang diterapkan karena model pembelajaran ini melibatkan semua siswa. Siswa mempuyai tugas masingmasing dalam kelompoknya dan siswa merasa tertantang untuk mengeluarkan pendapatnya ketika berdiskusi.

\section{Hasil Evaluasi}

Evaluasi belajar siswa diadakan pada akhir pertemuan dengan cara memberikan tes berbentuk pilihan ganda sebanyak 10 soal yang dikerjakan dalam waktu dua jam pelajaran. Hasil evaluasi siswa selengkapnya dapat dilihat pada tabel 9.

\section{Tabel 9. Ringkasan Hasil Evaluasi Siklus II}

\begin{tabular}{lc}
\hline Jumlah siswa yang mengikuti tes & 20 \\
\hline Jumlah siswa yang tuntas & 18 \\
\hline Jumlah siswa yang tidak tuntas & 2 \\
\hline Nilai tertinggi & 90 \\
\hline Nilai terendah & 50 \\
\hline Rata-rata nilai & 75 \\
\hline Prosentase ketuntasan & $90 \%$ \\
\hline
\end{tabular}

Dari tabel diatas dapat dilihat bahwa dari 20 siswa yang mengikuti evaluasi, terdapat 18 siswa yang tuntas dan 2 siswa tidak tuntas, sehingga ketuntasan belajar siswa pada siklus II ini mencapai $90 \%$ dengan nilai rata-rata 75 .

\section{Refleksi}

Berdasarkan data yang diperoleh dari tes evaluasi dan observasi yang dilakukan, terjadi peningkatan dari siklus sebelumnya. Ketuntasan klasikal sudah memenuhi standar yang ditetapkan yaitu sebesar 90\%. Aktivitas siswa termasuk dalam kategori aktif.

\section{Pembahasan}

Pembelajaran yang dilakukan dengan pembelajaran kooperatif tipe berpikir berpasangan berbagi dapat meningkatkan hasil belajar siswa dalam belajar matematika. Model pembelajaran ini dapat melatih siswa untuk berpikir, dan belajar bekerja sama dengan teman sebangku atau dengan pasangannya. Teknik ini memberi siswa kesempatan untuk bekerja sendiri serta bekerja dengan orang lain. Menurut Lie (2010), bahwa keunggulan dari teknik ini adalah optimalisasi partisipasi siswa, yaitu memberi kesempatan delapan kali lebih banyak kepada siswa untuk dikenali dan menunjukkan partisipasi mereka kepada orang lain. Pembelajaran kooperatif tipe berpikir berpasangan berbagi dapat mengembangkan 
kemampuan untuk memberikan pendapat atau gagasan dan dapat mengambil kesimpulan dari ide-ide yang dikemukakan oleh orang lain.

Dengan penerapan model pembelajaran kooperatif tipe berpikir berpasangan berbagi dapat memberikan kesempatan kepada siswa untuk mengungkapkan gagasan atau ide, baik dalam pasangan maupun dalam kelompoknya (Israil, 2019; Yuliati, 2018). Disamping itu, dalam interaksi di dalam kelas, siswa dapat menerima segala keterbatasan dan perbedaan yang ada dalam pembelajaran sehingga dapat meningkatkan motivasi dan memberi rangsangan untuk berpikir yang bermanfaat bagi proses pendidikan jangka panjang (Wirejati, 2019; Burungge, 2020; Taqiya et. Al., 2021).

Berdasarkan analisis data pada siklus I menunjukkan bahwa aktivitas siswa tergolong cukup aktif dengan rata-rata skor aktivitas siswa sebesar 10,3. Aktivitas guru dengan rata-rata skor 2,14 dengan kategori baik. Rata-rata nilai hasil belajar siswa adalah 66 dengan ketuntasan klsikal mencapai 80\%. Pencapaian tersebut belum memenuhi standar ketuntasan minimal yang ditetapkan yaitu sebesar $85 \%$. Pada siklus II, terdapat peningkatan aktivitas siswa yaitu pada siklus I rata-rata skor aktivitas siswa adalah 10,3 dengan kategori cukup aktif, pada siklus II terjadi peningkatan menjadi 14,22 dengan kategori sangat aktif. Aktivitas guru termasuk dalam kategori sangat baik dengan skor rata-rata 2,87. Nilai rata-rata hasil belajar siswa meningkat dari sebelumnya 66 menjadi 75. Ketuntasan klasikal mencapai 90\% meningkat dari ketuntasan klasikal pada siklus I yang hanya mencapai $80 \%$. Dengan demikian pada siklus II ini menunjukkan bahwa hasil belajarnya sudah mencapai ketuntasan klasikal.

Dari hasil penelitian di atas dapat dikatakan bahwa, penerapan model pembelajaran kooperatif tipe berpikir berpasangan berbagi dalam pembelajaran matematika dapat meningkatkan keaktifan siswa, hal tersebut didukung oleh adanya pemberian sikap kepada siswa yaitu guru berusaha untuk selalu menanamkan sikap kritis kepada siswa, sehingga terjadi komunikasi antara guru dan siswa. Ketercapaian ketuntasan hasil belajar pada siklus II menunjukkan bahwa penerapan model pembelajaran kooperatif tipe berpikir berpasangan berbagi dapat meningkatkan ketuntasan hasil belajar siswa Kelas X Multimedia di SMKN 1 Praya.

\section{Kesimpulan}

Berdasarkan hasil penelitian ini dapat disimpulkan bahwa penerapan model pembelajaran kooperatif tipe berpikir berpasangan berbagi dapat meningkatkan aktivitas siswa. Antusiasme siswa dalam belajar juga meningkat sehingga pembelajaran menjadi lebih aktif, kreatif, efektif dan bermakna. Hal ini dapat dilihat dari rata-rata skor aktivitas siswa pada siklusi I adalah 10,3 dengan kategori cukup aktif meningkat menjadi 14,22 pada siklus II dengan kategori sangat aktif. Selain itu, model pembelajaran kooperatif tipe berpikir berpasangan berbagi juga dapat meningkatkan hasil belajar siswa kelas X Multimedia SMKN 1 Praya Tengah. Hal ini dapat dilihat dari rata-rata nilai evaluasi hasil belajar siswa siklus I yaitu 66, rata-rata nilai evaluasi hasil belajar siswa siklus II sebesar 75. Sedangkan prosentase ketuntasan klasikal pada siklus I yaitu $80 \%$, dan meningkat pada siklus II sebesar $90 \%$.

\section{Saran}

Adapun saran yang disampaikan berdasarkan hasil penelitian ini yakni, (1) Bagi pendidik, hendaknya kreatif dalam memilih metode pembelajaran dan menerapkannya sesuai dengan bidang yang diajarkan dan minat belajar siswa. Adanya model pembelajaran kooperatif tipe berpikir berpasangan berbagi menjadi salah satu metode dalam pembelajaran sehingga 
pembelajaran menjadi lebih aktif, kreatif, efektif, inovatif dan menyenangkan. (2) Bagi peserta didik, hendaknya menjadikan pembelajaran kooperatif tipe berpikir berpasangan berbagi menjadi sebuah inovasi belajar untuk memudahkan pembelajaran matematika yang dianggap sulit dan pelajaran matematika akan menjadi labih menarik dan mudah dimengerti.

\section{Daftar Pustaka}

Arifin, Zaenal. (2009). Evaluasi Pembelajaran Prinsip-Teknik-Prosedur. Bandung:

Corebima, dkk. (2009). Penelitian Tindakan Kelas (Modul Diklat Sertifikasi Guru). Mataram: UNIVERSITAS MATARAM.

Burengge, S. (2020). Penerapan Model Pembelajaran Kooperatif Tipe STAD dengan Pendekatan Kontekstual bagi Siswa SDN 7 Tentena Sulawesi Tengah. Jurnal Paedagogy, 7(4), 275-280. doi:https://doi.org/10.33394/jp.v7i4.2832

Djamarah, Syaiful Bahri. (2002). Psikologi Belajar. Banjarmasin: PT RINEKA CIPTA.

Hamalik, Oemar. (2010). Proses Belajar Mengajar. Bandung: PT Bumi Aksara.

Isjoni. (2010). Pembelajaran Kooperatif. Pekanbaru: CV ALFABETA.

Israil, I. (2019). Implementasi Model Pembelajaran Cooperative Learning Tipe STAD untuk Meningkatkan Motivasi Belajar Siswa dalam Pembelajaran IPA di SMP Negeri 1 Kayangan. Jurnal Kependidikan: Jurnal Hasil Penelitian dan Kajian Kepustakaan di Bidang Pendidikan, Pengajaran dan Pembelajaran, 5(2), 117-123. doi:https://doi.org/10.33394/jk.v5i2.1807

Lie, Anita. (2010). Cooperative Learning. Jakarta: PT Gramedia.

Saufi, I., \& Rizka, M. (2021). Analisis Pengaruh Media Pembelajaran Film Dokumenter Terhadap Motivasi Belajar Siswa. Jurnal Teknologi Pendidikan : Jurnal Penelitian dan Pengembangan Pembelajaran, 6(1), 55-59. doi:https://doi.org/10.33394/jtp.v6i1.3626

Sya'i, S., Rizka, M., \& Gunawan, I. (2021). Studi Korelasi Antara Pendidikan dan Pelatihan (Diklat) Tutor PAUD dengan Peningkatan Kompetensi Mengajar. Jurnal Paedagogy, 8(3), 351-356. doi:https://doi.org/10.33394/jp.v8i3.3793

Taqiya, T., Sugiyono, T., \& Nugroho, A. (2021). Peningkatan Aktivitas dan Hasil Belajar Siswa pada Tema 8 Peristiwa Alam melalui Model Kooperatif Tipe STAD di Masa Pandemi Covid-19. Jurnal Paedagogy, 8(3), 369-376. doi:https://doi.org/10.33394/jp.v8i3.3892

Trianto. (2007). Model-model Pembelajaran Inovatif Berorientasi Konstruktivistik (Konsep, Landasan Teoritis - Praktis dan Implementasinya. Surabaya: Prestasi Pustaka.

Wirejati, W. (2019). Peningkatan Mutu Hasil Belajar Siswa Kelas IX.A SMPN 7 Pujut pada Materi Sistem Ekskresi Melalui Pembelajaran Kooperatif Tipe Student Teams Achievement Divisions. Jurnal Paedagogy, 6(2), 59-65. doi:https://doi.org/10.33394/jp.v6i2.2532

Yuliati, G. (2018). Peningkatan Hasil Belajar Matematika Siswa Kelas XI IPA 3 SMA Negeri 1 Batukliang Melalui Penggunaan Model Pembelajaran Student Teams Achievement Division. Jurnal Kependidikan: Jurnal Hasil Penelitian dan Kajian Kepustakaan di Bidang Pendidikan, Pengajaran dan Pembelajaran, 4(1), 31-40. doi:https://doi.org/10.33394/jk.v4i1.899 